OPEN ACCESS

Edited by:

Marcello Locatelli,

University of Studies G. d'Annunzio

Chieti and Pescara, Italy

Reviewed by:

Hesham Ali El Enshasy,

University of Technology Malaysia,

Malaysia

Phan Chia Wei

University of Malaya, Malaysia

*Correspondence:

Javad Sharifi-Rad

javad.sharifirad@gmail.com

Miquel Martorell

martorellpons@gmail.com

Alfred Maroy

amaroyi@ufh.ac.za

Natália Martins

ncmartins@med.up.pt

Specialty section: This article was submitted to

Ethnopharmacology,

a section of the journal

Frontiers in Pharmacology

Received: 29 May 2020

Accepted: 25 August 2020 Published: 16 September 2020

Citation:

Sharifi-Rad J, Butnariu M, Ezzat SM, Adetunji CO, Imran M, Sobhani SR,

Tufail T, Hosseinabadi $T$, Ramírez-Alarcón K, Martorell M, Maroyi A and Martins N (2020) Mushrooms-Rich Preparations on Wound Healing: From Nutritional to Medicinal Attributes.

Front. Pharmacol. 11:567518. doi: 10.3389/fphar.2020.567518

\section{Mushrooms-Rich Preparations on Wound Healing: From Nutritional to Medicinal Attributes}

\author{
Javad Sharifi-Rad $^{1 *}$, Monica Butnariu ${ }^{2}$, Shahira M. Ezzat ${ }^{3,4}$, Charles Oluwaseun Adetunji ${ }^{5}$, \\ Muhammad Imran ${ }^{6}$, Seyyed Reza Sobhani ${ }^{7}$, Tabussam Tufail ${ }^{6}$, Tahereh Hosseinabadi ${ }^{8}$, \\ Karina Ramírez-Alarcón ${ }^{9}$, Miquel Martorell ${ }^{9,10,11^{*}}$, Alfred Maroyi ${ }^{12 *}$ \\ and Natália Martins ${ }^{13,14 *}$
}

\begin{abstract}
1 Zabol Medicinal Plants Research Center, Zabol University of Medical Sciences, Zabol, Iran, ${ }^{2}$ Banat's University of Agricultural Sciences and Veterinary Medicine "King Michael I of Romania", Timisoara, Romania, ${ }^{3}$ Pharmacognosy Department, Faculty of Pharmacy, Cairo University, Cairo, Egypt, ${ }^{4}$ Pharmacognosy Department, Faculty of Pharmacy, October University for Modern Sciences and Arts (MSA), 6th of October, Dokki, Egypt, ${ }^{5}$ Applied Microbiology, Biotechnology and Nanotechnology Laboratory, Department of Microbiology, Edo University lyamho, Auchi, Nigeria, ${ }^{6}$ Faculty of Allied Health Sciences, University Institute of Diet and Nutritional Sciences, The University of Lahore, Lahore, Pakistan,

${ }^{7}$ Department of Community Nutrition, Faculty of Nutrition Sciences and Food Technology, Shahid Beheshti University of Medical Sciences, Tehran, Iran, ${ }^{8}$ Department of Pharmacognosy and Biotechnology, School of Pharmacy, Shahid Beheshti University of Medical Sciences, Tehran, Iran, ${ }^{9}$ Department of Nutrition and Dietetics, Faculty of Pharmacy, University of Concepción, Concepción, Chile, ${ }^{10}$ Centre for Healthy Living, University of Concepción, Concepción, Chile, ${ }^{11}$ Unidad de Desarrollo Tecnológico, UDT, Universidad de Concepción, Concepción, Chile, ${ }^{12}$ Department of Botany, University of Fort Hare, Alice, South Africa, ${ }^{13}$ Faculty of Medicine, University of Porto, Porto, Portugal, ${ }^{14}$ Institute for Research and Innovation in Health (i3S), University of Porto, Porto, Portugal
\end{abstract}

Mushrooms have a significant role in human diet as functional food and as a nutraceutical resource. The combination of its umami flavor, protein, vitamins, minerals and carbohydrates has meant that mushrooms could be considered a cheap food source for a long time in many countries. Moreover, mushrooms contain an excellent variety of bioactive metabolites that can be successful in both prevention and treatment of various human health hazards. In addition, extracts from medicinal mushrooms and their metabolites have been verified for wound treating with contribution to different mechanisms of the healing process. This review summarizes the nutritional value and composition of mushrooms, ethnobiology and ethnopharmacology, and wound healing potential.

Keywords: mushrooms, bioactive compounds, ethnobiology, ethnopharmacology, wound healing

\section{INTRODUCTION}

Mushrooms are macrofungi, including mostly basidiomycetes and some ascomycetes species (Chang and Miles, 2004; Lindequist et al., 2005; Wang et al., 2014). The estimated number of mushrooms species in the earth is 140,000 (Kim, 2017), comprising around 22,000 identified species (Lindequist et al., 2005). From long times ago mushrooms were extensively used worldwide for their nutritional and medicinal features, predominantly in some Asian, Northern and Central American countries (Badalyan, 2014). 
The cultivation of fruiting body and mycelium, the production of bioactive components in short time and the possibility of manipulation to optimize production are some of the most renowned mushrooms' advantages as a source of functional foods and beneficial natural molecules (Ferreira et al., 2009). From the perspective of nutrient source, mushrooms contain high protein and low-fat contents, along with a high amount of vitamins $\mathrm{B}, \mathrm{C}, \mathrm{D}$, and $\mathrm{K}$, minerals, including potassium and phosphorus, and also selenium as a trace element. They have also considerable amounts of dietary fibers (Badalyan, 2014), chitin and $\beta$-glucans as functional components (Manzi et al., 2001).

The main medicinal properties ascribed to mushrooms include antibiotic, antitumor, antiviral, immunostimulant and hypolipidemic activities (Chowdhury et al., 2015). Several researchers have reported anti-elastase, anti-collagenase, antihyaluronidase and anti-tyrosinase activities in mushroom extracts and their isolated compounds (Taofiq et al., 2016; Zengin et al., 2017). In the same line, wound healing promotion has been one of the most studied beneficial effects of mushrooms, described in different scientific literatures (Schepetkin and Quinn, 2006; Cheng et al., 2013). Mushrooms' medicinal properties are closely linked to its content in bioactive compounds, which mostly included polysaccharides, terpenoids, glucans, phenolic compounds, statins, lectins, among others. Melanin pigments, chitin and chitosan which are found in their cell wall along with extracellular enzymes are other effective molecules (Lindequist et al., 2005; Badalyan, 2014; Ruthes et al., 2016). The wound healing properties of mmushrooms include different mechanisms such as immune epithelial cells stimulation, and cytokines and growth factors release (Amin et al., 2015; Krupodorova et al., 2015). Thus, given the above listed aspects, the present review aimed to provide key insights on mushrooms nutritional value and composition, ethnobiology and ethnopharmacology, and wound healing potential.

\section{MUSHROOMS: NUTRITIONAL VALUE AND ITS ROLE IN OUR DIET}

\section{Mushrooms: The Role in Our Diet}

A balanced and healthy diet includes plants, plant-derived products, and mushrooms (Reis et al., 2017). Their production and consumption have continuously increased over time due its nutritional value and health benefits (Aida et al., 2009; Reis et al., 2017). Nowadays, the use of mushrooms has markedly grown in pharmaceutical, nutraceutical, and cosmeceutical industries (Rathore et al., 2017). Indeed, edible mushrooms have a high nutritional value, more than any vegetable or fruit (Manjunathan and Kaviyarasan, 2011), and have been eaten for their flavor, economic and ecological benefits, and therapeutic properties for many years (Sánchez, 2017). Their texture and enjoyable flavor properties make them a feasible alternative for meat. Its low energetic density, with about $92 \%$ water, allows to reduce the energetic density of the final meal, when mushrooms are used instead of other higher energy-dense ingredients (Feeney et al., 2014b). The most cultivated and consumed mushrooms worldwide is Agaricus bisporus, followed by Pleurotus spp. and Lentinula edodes (Aida et al., 2009; Roncero-Ramos and Delgado-Andrade, 2017).

\section{Energetic Value and Macronutrients Content}

Due to their low-fat content, mushrooms are low in calories (Muszyńska et al., 2018). The total energetic value of mushrooms is between 250 and 350 calories $/ \mathrm{kg}$ of fresh mushrooms (Panneerselvam et al., 2009; Sánchez, 2010). The dry matter of mushrooms comprise around 50\% to $65 \%$ total carbohydrates, $19 \%$ to $35 \%$ proteins, and $2 \%$ to $6 \%$ fat (Rathore et al., 2017). Edible mushroom comprises a maximum number of all essential amino acids (Hayes, 1976), with arginine, glutamic acid, and aspartic acid being the most abundant ones (Manzi et al., 1999). Thus, mushrooms can be considered an great alternative to animal products (Dembitsky et al., 2010). Indeed, tryptophan and lysine, which are absent in vegetables, are present at high concentrations when compared to cysteine and methionine (Murugesan, 2017).

Alcoholic sugars, like mannitol and trehalose, are some carbohydrates components present in mushrooms (Jain and Roy, 2009). Regarding fats, mushrooms are rich in polyunsaturated, monoinsaturated and saturated fatty acids, as palmitic, oleic, and linoleic acids (Kavishree et al., 2008; Muszyńska et al., 2018).

\section{Vitamins and Minerals}

Mushrooms are rich in niacin (B3), pantothenic acid (B5) and riboflavin (B2) (Feeney et al., 2014b; Murugesan, 2017), but other vitamins, such as thiamine (B1), pyridoxin (B6), cobalamin (B12), biotin (B7) and D have also been reported (Pankavec et al., 2019; Rózsa et al., 2019). The only non-animal-based food that contains vitamin D are mushrooms (Feeney et al., 2014b; Rathore et al., 2017), and curiously the content of vitamin B12 in mushrooms is similar to that reported for beef, liver, and fish (Feeney et al., 2014b).

Moreover, mushrooms are also rich in minerals, such as potassium, calcium, phosphorus, and magnesium. Because of its low sodium and high potassium concentration, they have a $\mathrm{Na}^{+} / \mathrm{K}^{+}$ratio less than 0.6 , being thus a good food option amongst other vegetables for hypertense individuals (Nieman et al., 1992; Rajarathnam et al., 1998). Indeed, mushrooms are an excellent source of selenium and copper, with high bioavailability (Feeney et al., 2014b; Murugesan, 2017). Mushrooms have also an interesting content in tocopherols, carotenoids, ascorbic acid, phenolics, and ergosterol, being even most abundant than that found in most vegetables and fruits (Sánchez, 2017).

On the other side, mushrooms are also a good source of different dietary fiber, including $\beta$-glucans, polysaccharideprotein complexes (PSPC), chitin, hemicelluloses, mannans, and xylans (Pardeshi and Pardeshi, 2009; Rathore et al., 2017). Thus, edible mushrooms consumption can easily provide up to $25 \%$ of the recommended dietary fiber intake (Cheung, 2010). 


\section{Secondary Metabolites in Mushrooms}

Several bioactive compounds are present in mushrooms, such as cinnamic acid, ergosterol, and p-coumaric, p-hydroxybenzoic and protocatechuic acids. The bioactive compounds with special pharmacological value present in shiitake mushroom are lentinan $\left[\mathrm{C}_{42} \mathrm{H}_{72} \mathrm{O}_{36}\right]$, eritadenine or lentinacin $\left[\mathrm{C}_{9} \mathrm{H}_{11} \mathrm{~N}_{5} \mathrm{O}_{4}\right]$, and ergotamine $\left[\mathrm{C}_{33} \mathrm{H}_{35} \mathrm{~N}_{5} \mathrm{O}_{5}\right]$ (Ribeiro et al., 2006).

\section{A Sustainable Food Choice}

As a result of its ability to control environmental factors, land use, and related energy and water needs during growing mushrooms, its production is consistent with sustainable food supply (Feeney et al., 2014b). Indeed, mushrooms have a small environmental footprint and require relatively little water content or land (Feeney et al., 2014a). Therefore, mushroom can be considered a sustainable food choice.

\section{MUSHROOMS: FROM ETHNOBIOLOGY TO ETHNOPHARMACOLOGY}

Mushrooms contain a fruiting body collected of a pileus (cap), lamellae (gills), stipe (stalk), and mycelium, the root absorb the nutrients (Verma et al., 2019). In historic times, mushrooms were considered part of the plant kingdom, but the present taxonomy recognizes fungi as an independent group of organisms under the Mycota kingdom, generally due the presence of chitin inside their cell walls. Although in wild mushrooms are seasonal and can be collected and used, they can be domesticated through spore culture.

Mushrooms are mysterious in their composition, containing umami-flavored, some medicinal, some hallucinogenic/ psychoactive, while some poisonous compounds. Additionally, various fungal species also accumulate heavy metals in their fruit bodies. Currently, the most commonly used mushrooms as significant health boosters include Chaga (Inonotus obliquus), Cordyceps (Cordyceps sinensis), Lion's Mane (Hericium erinaceus), Reishi (Ganoderma lucidum), Shiitake (L. edodes), and Turkey Tail (Trametes versicolor).

Mushrooms are an inexhaustible source of immunomodulating biomolecules, whose effects in the treatment of cancer, infectious or immunological disorders have already been clinically demonstrated (Yang et al., 2013; Dai et al., 2015). Mushrooms contain immunostimulant compounds, such as $\beta$-glucans, polyinosinic: polycytidylic acid and lip polysaccharide, that makes stronger and boost the immune system activity. Moreover, mushrooms folate plays an important role in DNA synthesis and repair (Trovato et al., 2017). At present, there are over 270 recognized fungal species for their various biological activities (such as adaptogenic, anti-inflammatory, antimicrobial, antioxidant, hepatoprotective, hypocholesterolemic). As their cultivation has grown for food purposes, mushrooms have become increasingly used as dietary supplements against various diseases and associated health problems (Ferreira et al., 2009). Additionally, their anti-atherogenic, hepatoprotective, antinociceptive, anti-inflammatory, antidiabetic and antioxidant effects have also been reported (Lindequist et al., 2005; Badalyan, 2014; Ruthes et al., 2016). In last decades, several scientific researches performed in Japan, China, and Korea, and lately in the United States, have proved the mushrooms potential for the prevention and treatment of some chronic diseases, like cancer and hypertension (Manzi et al., 2001; Kimura, 2013) and heart disease (Brzezicha-Cirocka et al., 2019). At the present, in some Asian countries several mushroom extracts are consumed in cancer treatment as adjuvant care in addition to other therapies (Chowdhury et al., 2015).

Internationally, the consumption of various mushrooms species in the form of dietary supplements has been approved by a number of specialized organizations, such as European Novel Food Regulations, Complementary Medicine in the UK, National Health Service, German Federal Health Agency; Japan Foods for Specific Health Use (FOSHU) - the largest in the world; USA - Federal Food Drug and Cosmetic Act, Dietary Supplement Health and Education Act (DSHEA), National Institute of Health (NIH), and American Herbal Products Association (AHPA) (Roupas et al., 2012). Most studies have been conducted by specialized centers in the treatment of various cancers, acquired immunodeficiency syndrome (AIDS) and other illnesses caused by an imbalanced immune system. Studies on some mushroom species have also shown their ability to support the body in the interferon' synthesis (Matuszewska et al., 2019).

\section{MUSHROOMS EFFECTS: EMPHASIS ON WOUND HEALING POTENTIAL}

Wound healing as a normal biological process, that may be divided into 4 phases: blood clotting (hemostasis), inflammation, tissue growth (proliferation), and tissue remodeling (maturation) (Guo and Dipietro, 2010; Amin et al., 2015). Wound repair involves many cell types populations and molecular mediators, and is consented as a physiological mechanism using the immune system, the complex skin repair process (Abdulla et al., 2010; Chen et al., 2020). Several factors can repair ulcers, affecting one or more phases in the process (Guo and Dipietro, 2010). Briefly, wound healing involves an increase in collagen deposition (Portera et al., 1997) and regulation of balance and occlusion by blood platelets (Li et al., 2012). Medicinal mushroom extracts and their metabolites have been verified for wound treating, with contribution in different mechanisms, including immune epithelial cells stimulation, extracellular matrix, cytokines, growth factors, reactive oxygen species (ROS), and various inflammatory intermediates (Amin et al., 2015; Krupodorova et al., 2015). The efficiency of wound healing process is largely dependent of the balance of proinflammatory and proregenerative signals, which are mediated by cytokines (Sureda et al., 2016; Nosenko et al., 2019). Figure 1 summarizes the wound healing process and the role of mushrooms in the different steps. 


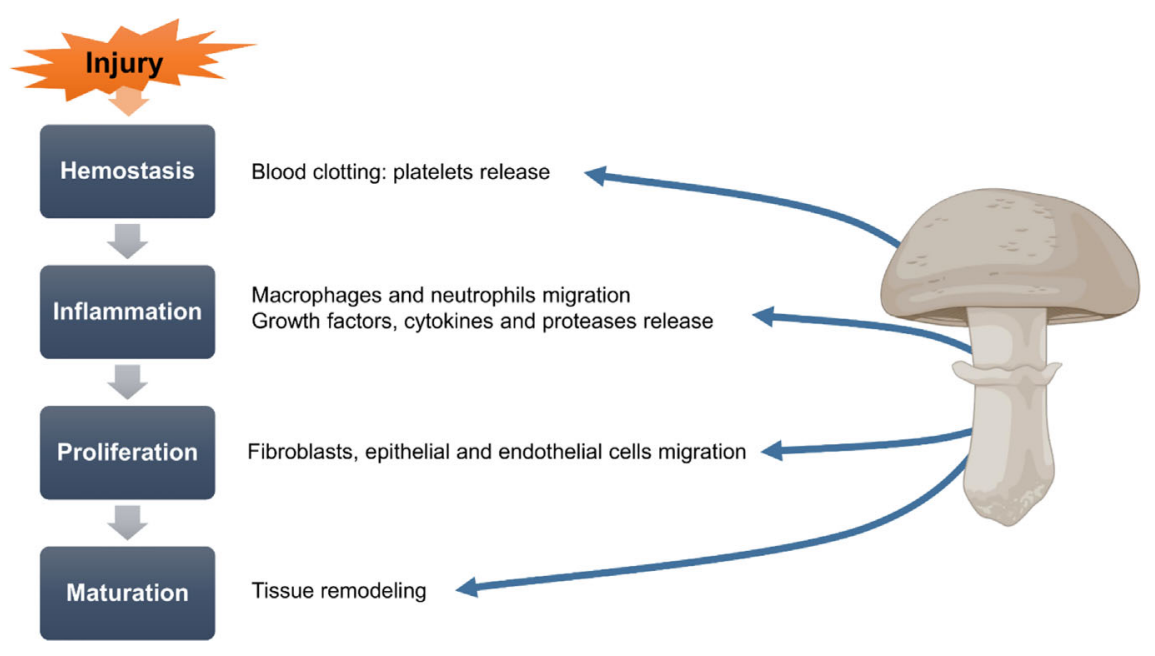

FIGURE 1 | Role of mushrooms in the wound healing process.

Browder et al. (1990) extensively studied glucan as a potent macrophage stimulant. The $1 \rightarrow 3 \beta$-glucans of mushrooms may recruit macrophages to the wound site as mechanism of wound healing. In fact, $\beta$-glucans is thought to mediate effects through activation of macrophages, neutrophils, natural killer (NK) cells, and lymphocytes. Moreover, it has been reported an immunostimulatory activity and enhance wound healing of $\beta$ glucans by increasing macrophage infiltration into the injury sites and stimulating tissue regeneration (Minutti et al., 2017). In addition, $\beta$-glucans directly increase the synthesis of types I and III collagen (Kwon et al., 2009; Cheng et al., 2013), stimulating the collagen regeneration and helping the wound healing (Portera et al., 1997). The use of $\beta$-glucan in combination with collagen matrix wound dressing reduced the requirement of various analgesics and dressing changes in partial-thickness burns in children (Delatte et al., 2001). In a rat model, the combination of $\beta$-glucans from mushroom with poly vinyl alcohol speeded up the wound healing time by $48 \%$ (compared to cotton gauze) (Huang and Yang, 2008). In induced ulceration rats, $\beta$-glucan obtained from both Ganoderma lucidum and Lentinus edodes raised serum antioxidant enzymes activities and decreased levels of serum mucosal interleukin-2 (IL-2) and tumor necrosis factor (TNF)- $\alpha$ (Gao et al., 2004a; Gao et al., 2004b; Yu et al., 2009). The suppression of TNF- $\alpha$ enhances wound healing increasing epithelial cell proliferation and gastric blood flow and decreased epithelial apoptosis (Gao et al., 2002). Water-soluble $\beta$-glucan obtained from Piptoporus betulinus fruiting bodies promoted cell migration on in vitro scratch assay on Caco-2 cells (De Jesus et al., 2018). Epithelial cell migration seems to be orchestrated by integrin-induced FAK/ Src signaling pathway (Zhao et al., 2016). $\beta$-Glucans from Schizophyllum commune provoked re-epithelialization through integrin/FAK/Src signaling pathway and activated dermal transformation via integrin or ROS production (Seo et al., 2019).
In short, the wound healing property of mushrooms in many studies have been moderately associated to their rich content in polysaccharides. For example, G. lucidum aqueous extract, Ganoderma tsugae (Chien et al., 2008) and polysaccharides form Agaricus blazei and Phellinus gilvus (Bae et al., 2005b) have been reported as useful agents in wound healing with several associated mechanisms (Krupodorova et al., 2015). The polysaccharides from G. lucidum can bind through specific receptors or serum-specific proteins to leucocyte surfaces and alter their activities of macrophage, T-helper, NK cells, and other effector cells (Müller et al., 1996; Mueller et al., 2000). Moreover, G. lucidum polysaccharides are potent immune-modulating agents (Gao and Zhou, 2002). The polysaccharides of P. gilvus decreased IL-1 expression in skin of burn wound-treated rats (50 or $100 \mathrm{mg} / \mathrm{kg}$ b. w.) (Sui et al., 2010). P. gilvusisolated polysaccharides reduced wound contraction and enhanced the re-epithelialization of the 6-mm circular wounds in streptozotocin (STZ)-induced diabetic rat by topical application twice a day for 5 days (Bae et al., 2005a). G. lucidum hot aqueous extract was standardized to contain total polysaccharides $(25.1 \%)$, ganoderic acid A (0.45\%), and adenosine $(0.069 \%)$ (Cheng et al., 2013). A 10\% aqueous extract cream of this mushroom was tested on wounds in the posterior neck region of STZ-induced diabetic rats. The mushroom extract accelerated wound closure more than the standard Intrasite gel. Moreover, the antioxidant activity was significantly higher in the serum of treated rats, and oxidative markers, proteins and lipids were lowered. Another study by Gupta et al. (2014) has shown that the aqueous lyophilized extract of G. lucidum from the Indian Himalayan region promoted the healing efficacy on wound dermal excision in experimental rats. Ling Zhi-8 (LZ-8) is an immunomodulatory protein isolated from G. lucidum mycelia (Lin et al., 2014). Ten $\mu \mathrm{L}$ of $1 \mathrm{mg} / \mathrm{ml} \mathrm{LZ-8}$ protein solution dropped on the wound in 
TABLE 1 | Wound healing activities of mushrooms

\section{Mushroom spp.}

Agaricus bisporus Agaricus blazei

Agaricus sylvaticus

Agaricales

Family

Lectin $(0-100 \mathrm{mg} / \mathrm{ml}$

Properties/Mechanism of action

Dose-dependent inhibition of proliferation and lattice contraction in an in vitro model

Impact on interleukin (IL)-1 expression in skin of burn wound-treated rats $(50$ and $100 \mathrm{mg} / \mathrm{kg}$

b. w.

Crude extract (proteins, phenols, $\beta$-glucans, Enhanced wound healing in Wistar rats ( $1 \mathrm{ml}$ of gel at $10 \%$ Agaricus sylvaticus for 14 days) phenols, chlorogenic, caffeic, coumaric and Phenols promoted the healing process

benzoic acids)

Auricularia auricula Auriculariaceae

Polysaccharides extracts $(0.1,1$ and 10 $\mathrm{mg} / \mathrm{ml}$

\section{Acidic polysaccharides}

Calvatia gigantean Agaricaceae Unspecified

Crinipellis

schevczenkovi

Daldinia concentrica Hypoxylaceae

Fomes fomentarius $\quad$ Polyporaceae

Ganoderma lucidum Basidiomycetes

Wound healing effect with $100 \mu \mathrm{g}$ per wound for A. auricula (140.43\%) in ex vivo porcine skin wound healing model

Anticoagulant effects by improving catalysis of thrombin reticence by antithrombin and prevention of platelet aggregation

Mushrooms consumption enhanced wound healing. Used for curing stomach upset and to cure stomach pains in woman during menstruation.

Powdered mushrooms mycelium (100 mg) Promoted wound healing and histology of healed wounds on the $5^{\text {th }}$ day

Crude extract (alkaloids, flavonoids,

phenols, tannins, terpenoids, and saponins)

Unspecified

Polysaccharides-rich extract

Increased wound healing activity in albino Wistar rats by excision wound model

Ash combined with oil on skin ailments exerted wound healing promotion

Topical application with $10 \% \mathrm{w} / \mathrm{w}$ enhanced wound healing in STZ-induced diabetic rats

\begin{tabular}{|c|c|c|}
\hline $\begin{array}{l}\text { Ganoderma } \\
\text { praelongum }\end{array}$ & Basidiomycetes & Unspecified \\
\hline Hericium erinaceus & Aphyllophoromycetidea & $\begin{array}{l}\beta \text {-glucan polysaccharides } \\
\text { Unspecified }\end{array}$ \\
\hline Lentinus edodes & Marasmiaceae & $\begin{array}{l}\text { Unspecified } \\
\text { Polysaccharide }\end{array}$ \\
\hline Lycoperdon echinatum & Agaricaceae & Unspecified \\
\hline Lycoperdon pusilum & Agaricaceae & Unspecified \\
\hline Phallus impudicus & Phallaceae & Unspecified \\
\hline Phellinus gilvus & Hymenochaetaceae & Polysaccharide \\
\hline $\begin{array}{l}\text { Pisolithus arhizus } \\
\text { (Scop.) Rauschert }\end{array}$ & Sclerodermataceae & Unspecified \\
\hline
\end{tabular}

Crude extract containing $5 \% \mathrm{v} / \mathrm{v}$ ethanol, absolute methanol and deionized water

(Batterbury et al., 2002)

Polysaccharide fractions $(0.1,0.5$, or $1.0 \mathrm{~g} /$ kg daily; intragastrically, for 14 days

Unspecified

Unspecified

Immunomodulatory protein (Ling Zhi-8)

Powdered mushrooms mycelium (100 mg)

Aqueous lyophilized extract

Wound healing promotion. Primary and secondary triterpenes $(0.156 \mathrm{mg} / \mathrm{ml})$ from the

methanol extract enhanced the healthy proliferation and migration of keratinocytes with no cytotoxic or aberrant morphological effects

Marked healing promotion on acetic acid-induced ulcers in rats

et al., 2010)

(Da Silva et al., 2018)

Khamlue et al., 2012)

(Yoon et al., 2003)

(Thangaraj et al., 2017)

(Krupodorova et al.,

2015)

(Thangaraj et al., 2017)

(Malik et al., 2017)

(Cheng et al., 2013)

(Montalbano, 2018)

Crude extract improved wound healing

Crude extract decreased gastric ulceration in rats

Accelerated wound healing in rat liver tissues after monopolar electrosurgery

(Gao et al., 2004b)

(Dora and Hena, 2016)

(Rony et al., 2011)

(Lin et al., 2014)

(Krupodorova et al.,

2015)

In experimental rats improved wound healing, enhanced healing activity, evidenced by an ～(Gupta et al., 2014) increase in wound contraction, collagen accumulation, hexosamine, and total protein contents

Crude extract enhanced wound healing

(Ameri et al., 2013)

Accelerated wound healing in rats

Crude extract (20,30 and $40 \mathrm{mg} / \mathrm{ml}$ ) accelerated wound healing enclosure in experimentally (Abdulla et al., 2011)

wounded male rats

Crude extract enhanced wound healing

(Sokół et al., 2016)

Increased serum antioxidant enzymes activities and decreased serum mucosal IL-2 and

tumor necrosis factor (TNF)- $\alpha$ levels in rats with oral ulceration. The protective action involve an oxidant mechanisms.

Crude extract enhanced wound healing

Crude extract enhanced wound healing

(Yu et al., 2009)

Mushroom consumption enhanced wound healing

Increased dermal wound healing in STZ-induced diabetic rats by topical application twice a

day for 5 days

Crude extract enhanced wound healing

(Chang and Miles, 2004)

(Rai et al., 2005)

(Malik et al., 2017)

(Bae et al., 2005a)

(Mohamed and Dix

1988) 

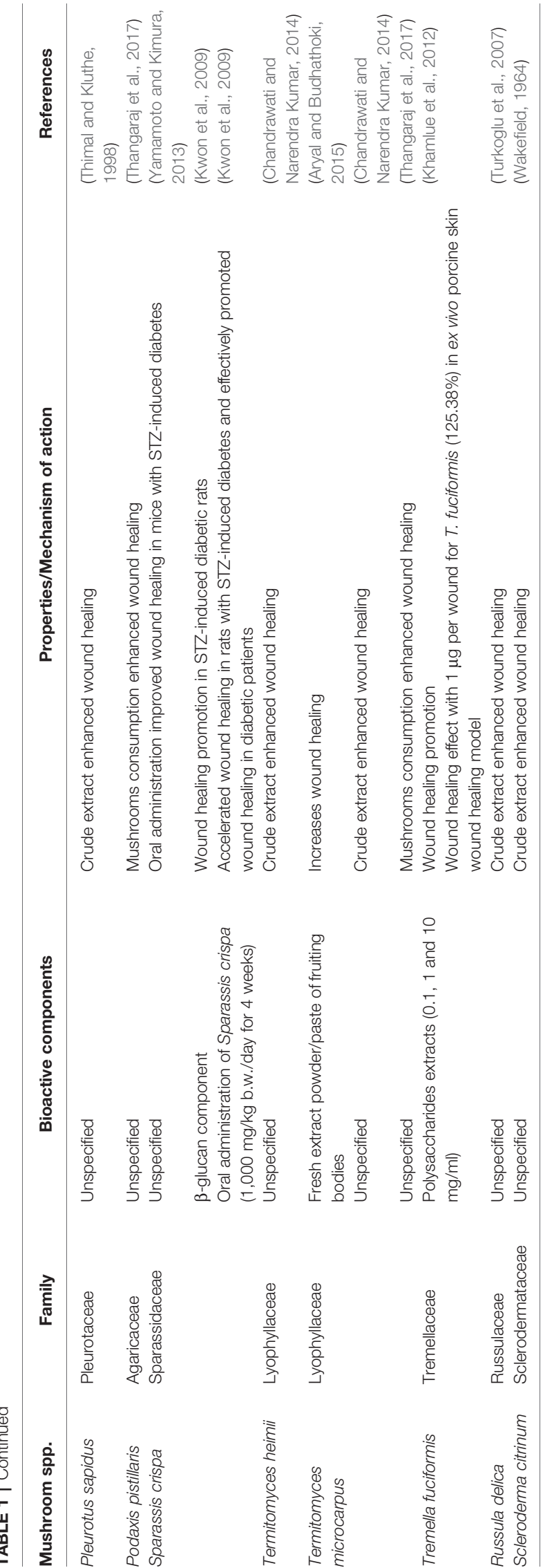

rat liver tissues after monopolar electrosurgery significantly increases wound healing and decreased nuclear factor- $\kappa \mathrm{B}$ (NF$\kappa \mathrm{B})$, caspase- 3 and apoptosis. The in vivo wound healing activity of aqueous extracts of G. lucidum and Crinipellis schevczenkovi (100 mg powder mycelium/1 ml water for injections) were investigated using the excision wound healing model on albino mice line (Krupodorova et al., 2015). The topical application of C. schevczenkovi mycelium extract induced wound healing on $3^{\text {th }}$ day, while on the $6^{\text {th }}$ day, both extracts induced a complete healing ( $8^{\text {th }}$ day in control group).

$H$. erinaceus, with a rich content on $\beta$-glucan polysaccharides, have exhibited wound healing acceleration in experimental rats (Khan et al., 2013). H. erinaceus freeze-dried fruiting bodies reduced ulceration as pre-treatment ( 250 and $500 \mathrm{mg} / \mathrm{kg}$ b.w.) in ethanol-induced gastric ulcers in rats (Abdulla et al., 2008). In addition, the oral administration of the medicinal mushroom Sparassis crispa (>40\% $\beta$-glucans) at a dose of $1.000 \mathrm{mg} / \mathrm{kg}$ b.w. per day, for 4 weeks, significantly accelerated the wound closure through increasing the collagen regeneration, macrophage and fibroblast migration, and wounds epithelialization in STZinduced diabetic rats (Kwon et al., 2009). The receptors of $\beta$ glucans are present in human dermal fibroblasts making these can receive direct signals from glucans promoting wound healing not only by activating macrophages, but also by stimulating fibroblasts (Kougias et al., 2001). After $\beta$-glucan stimulation, fibroblasts activate two translation factors, activator protein-1 (AP-1) and specific protein-1 (SP-1), and two signaling pathways, NF- $\kappa \mathrm{B}$ and nuclear factor-1 (NF-1), to enhance the immune response, hyperplasia and the expression of collagen precursor genes (Kougias et al., 2001; Lowe et al., 2002).

Antrodia camphorata extract, rich in total polyphenols and flavonoids, have exhibited noteworthy wound healing effects in rats, leading to an increase in wound constriction and collagen accumulation. In another study, A. camphorata extract significantly promoted wound healing in vivo by observation of less inflammatory cells and more collagen synthesis in the injured tissues, and also in vitro by promoting fibroblast cells proliferation (Amin et al., 2015). Furthermore, A. bisporus, rich in polysaccharides, phenolic compounds and lectin, has also been reported effective in controlling wound procedures afterward glaucoma surgery (Krupodorova et al., 2015). The edible mushroom lectin from A. bisporus tested on Tenon's capsule fibroblasts in vitro models of wound healing showed a dose-dependent inhibition of proliferation and lattice contraction (Batterbury et al., 2002). More studies related with wound healing activities of mushrooms are shown in Table $\mathbf{1 .}$

\section{CONCLUDING REMARKS AND UPCOMING PERSPECTIVES}

Mushrooms have been eaten for many years due to their flavor, economic and ecological benefits, and therapeutic properties. With the research advances, numerous bioactive compounds obtained from mushrooms have been looked as responsible for their biological and therapeutic properties, with their anti-atherogenic, 
hepatoprotective, antinociceptive, anti-inflammatory, antidiabetic and antioxidant effects being the most remarkable ones. Nonetheless, the wound healing potential of mushrooms have also been increasingly reported, linked to their richness in polysaccharides and phenolic compounds. However, some species can cause extremely serious, sometimes deadly poisonings, being thus of extreme relevance to deepen knowledge on this field. Thus, further studies are needed to assess the mushrooms-derived bioactive compounds potential and their healing properties, as well as of the extracts from which they are derived. Nevertheless, the use of mushroom components and extracts in cosmetics may be considered a niche of attention, due to their remarkable wound healing properties.

\section{REFERENCES}

Abdulla, M. A., Noor, S., Wong, K.-H., and Ali, H. M. (2008). Effect of culinarymedicinal lion's mane mushroom, Hericium erinaceus (Bull.: Fr.) Pers.(Aphyllophoromycetideae), on ethanol-induced gastric ulcers in rats. Int. J. Med. Mushrooms 10. doi: 10.1615/IntJMedMushr.v10.i4.40

Abdulla, M. A., Ahmed, K. A.-A., Abu-Luhoom, F. M., and Muhanid, M. (2010). Role of Ficus deltoidea extract in the enhancement of wound healing in experimental rats.

Abdulla, M. A., Fard, A. A., Sabaratnam, V., Wong, K. H., Kuppusamy, U. R., Abdullah, N., et al. (2011). Potential activity of aqueous extract of culinarymedicinal Lion's Mane mushroom, Hericium erinaceus (Bull.: Fr.) Pers. (Aphyllophoromycetideae) in accelerating wound healing in rats. Int. J. Med. Mushrooms 13, 33-39. doi: 10.1615/IntJMedMushr.v13.i1.50

Aida, F., Shuhaimi, M., Yazid, M., and Maaruf, A. (2009). Mushroom as a potential source of prebiotics: a review. Trends Food Sci. Technol. 20, 567-575. doi: 10.1016/j.tifs.2009.07.007

Ameri, A., Rajive, B. B., Vaidya, J. G., Apte, K., and Deokule, S. S. (2013). AntiStaphylococcal and wound healing activities of Ganoderma praelongum and Glycyrrhiza glabra formulation in mice. Int. J. Appl. Res. Natural Prod. 6, 27-31.

Amin, Z. A., Ali, H. M., Alshawsh, M. A., Darvish, P. H., and Abdulla, M. A. (2015). Application of Antrodia camphorata promotes rat's wound healing in vivo and facilitates fibroblast cell proliferation in vitro. Evidence-Based Complement. Altern. Med. 2015, 317693. doi: 10.1155/2015/317693

Aryal, H. P., and Budhathoki, U. (2015). Phyto-Chemical Study of Termite's Mushroom in Nepal: An Ethnomycological Approach. J. Plant Sci. Res. 2, 121.

Badalyan, S. M. (2014). "Potential of mushroom bioactive molecules to develop healthcare biotech products" in Proceedings of the 8th International Conference on mushroom biology and mushroom products (ICMBMP8). (New Delhi: Yugantar Prakashan Pvt. Ltd), 373-378.

Bae, J.-S., Jang, K.-H., and Jin, H.-K. (2005a). Polysaccharides isolated from Phellinus gilvus enhances dermal wound healing in streptozotocin-induced diabetic rats. J. Veterin. Sci. 6, 161-164. doi: 10.4142/jvs.2005.6.2.161

Bae, J.-S., Jang, K.-H., Park, S.-C., and Jin, H. K. (2005b). Promotion of dermal wound healing by polysaccharides isolated from Phellinus gilvus in rats. J. Veterin. Med. Sci. 67, 111-114. doi: 10.1292/jvms.67.111

Batterbury, M., Tebbs, C., Rhodes, J., and Grierson, I. (2002). Agaricus bisporus (edible mushroom lectin) inhibits ocular fibroblast proliferation and collagen lattice contraction. Exp. Eye Res. 74, 361-370. doi: 10.1006/exer.2001.1133

Browder, W., Williams, D., Pretus, H., Olivero, G., Enrichens, F., Mao, P., et al. (1990). Beneficial effect of enhanced macrophage function in the trauma patient. Ann. Surg. 211, 605.

Brzezicha-Cirocka, J., Grembecka, M., Grochowska, I., Falandysz, J., and Szefer, P. (2019). Elemental composition of selected species of mushrooms based on a chemometric evaluation. Ecotoxicol. Environ. Saf. 173, 353-365. doi: 10.1016/ j.ecoenv.2019.02.036

Chandrawati, P. S., and Narendra Kumar, T. N. (2014). Macrofungal wealth of Kusumhi forest of gorakhpur, UP, India. Am. Int. J. Res. Formal Appl. Natural Sci. 5, 71-75.

\section{AUTHOR CONTRIBUTIONS}

All authors contributed equally to the manuscript. Conceptualization: JS-R. Validation investigation, resources, data curation, writing: all authors. Review and editing: JS-R, $\mathrm{MM}, \mathrm{AM}$, and NM. All authors contributed to the article and approved the submitted versión.

\section{FUNDING}

This work was supported by CONICYT PIA/APOYO CCTE AFB170007.

Chang, S. T., and Miles, P. G. (2004). Mushrooms cultivation, nutritional value, medicinal effect and environmental impact, 2nd Edn. (CRC Press), 480.

Chen, S.-N., Wu, Y.-S., Chen, S., Chang, Y.-C., and Lu, C.-L. (2020). Novel Application of Immunomodulatory Mushroom Polysaccharide ( $\beta$-Glucan) and Triterpenes for Diabetic Wound Care. IntechOpen. doi: 10.5772/ intechopen. 93122

Cheng, P.-G., Phan, C.-W., Sabaratnam, V., Abdullah, N., Abdulla, M. A., and Kuppusamy, U. R. (2013). Polysaccharides-rich extract of Ganoderma lucidum (MA Curtis: Fr.) P. Karst accelerates wound healing in streptozotocin-induced diabetic rats. Evidence-Based Complement. Altern. Med. 2013.

Cheung, P. C. (2010). The nutritional and health benefits of mushrooms. Nutr. Bull. 35, 292-299. doi: 10.1111/j.1467-3010.2010.01859.x

Chien, C.-C., Tsai, M.-L., Chen, C.-C., Chang, S.-J., and Tseng, C.-H. (2008). Effects on tyrosinase activity by the extracts of Ganoderma lucidum and related mushrooms. Mycopathologia 166, 117. doi: 10.1007/s11046-008-9128-x

Chowdhury, M. M. H., Kubra, K., and Ahmed, S. R. (2015). Screening of antimicrobial, antioxidant properties and bioactive compounds of some edible mushrooms cultivated in Bangladesh. Ann. Clin. Microbiol. Antimicrob. 14, 8. doi: 10.1186/s12941-015-0067-3

Da Silva, G. R., Franklin, V., Cambuí, J. M., De Almeida, D. T., Wadt, N. S. Y., Cardoso, V. O., et al. (2018). Effect of Agaricus Sylvaticus (Schaeffer) Extract in Rats Skin Wound Healing. Biomed. J. Sci. Tech. Res. 10.

Dai, X., Stanilka, J. M., Rowe, C. A., Esteves, E. A., Nieves, C.Jr., Spaiser, S. J., et al. (2015). Consuming Lentinula edodes (Shiitake) Mushrooms Daily Improves Human Immunity: A Randomized Dietary Intervention in Healthy Young Adults. J. Am. Coll. Nutr. 34, 478-487. doi: 10.1080/07315724.2014.950391

De Jesus, L. I., Smiderle, F. R., Ruthes, A. C., Vilaplana, F., Dal'lin, F. T., MariaFerreira, D., et al. (2018). Chemical characterization and wound healing property of a $\beta$-D-glucan from edible mushroom Piptoporus betulinus. Int J. Biol. Macromol. 117, 1361-1366. doi: 10.1016/j.ijbiomac.2017.12.107

Delatte, S. J., Evans, J., Hebra, A., Adamson, W., Othersen, H. B., and Tagge, E. P. (2001). Effectiveness of beta-glucan collagen for treatment of partial-thickness burns in children. J. Pediatr. Surg. 36, 113-118. doi: 10.1053/jpsu.2001.20024

Dembitsky, V. M., Terent'ev, A. O., and Levitsky, D. O. (2010). Amino and fatty acids of wild edible mushrooms of the genus Boletus. Records Natural Prod. 4, 218.

Dora, J., and Hena, V. (2016). Phytochemical, Antimicrobial Analysis and wound Healing Activities of Ganoderma lucidium. IOSR J. Pharm. Biol. Sci. 11, 59-62.

Feeney, M. J., Dwyer, J., Hasler-Lewis, C. M., Milner, J. A., Noakes, M., Rowe, S., et al. (2014a). Mushrooms and health summit proceedings. J. Nutr. 144, 1128S-1136S. doi: 10.3945/jn.114.190728

Feeney, M. J., Miller, A. M., and Roupas, P. (2014b). Mushrooms-biologically distinct and nutritionally unique: exploring a "third food kingdom". Nutr. Today 49, 301. doi: 10.1097/NT.0000000000000063

Ferreira, I. C., Barros, L., and Abreu, R. (2009). Antioxidants in wild mushrooms. Curr. Med. Chem. 16, 1543-1560. doi: 10.2174/092986709787909587

Gao, Y., and Zhou, S. (2002). The Immunomodulating Effects of Ganoderma lucidum (Curt.: Fr.) P. Karst. (Ling Zhi Reishi Mushroom) (Aphyllophoromycetideae) 4, 11.

Gao, Y., Zhou, S., Wen, J., Huang, M., and Xu, A. (2002). Mechanism of the antiulcerogenic effect of Ganoderma lucidum polysaccharides on indomethacin- 
induced lesions in the rat. Life Sci. 72, 731-745. doi: 10.1016/S0024-3205(02) 02301-9

Gao, Y., Lan, J., Dai, X., Ye, J., and Zhou, S. (2004a). A phase I/II study of Ling Zhi mushroom Ganoderma lucidum (W. Curt.: Fr.) Lloyd (Aphyllophoromycetideae) extract in patients with type II diabetes mellitus. Int. J. Med. Mushrooms 6. doi: 10.1615/IntJMedMushr.v6.i1.30

Gao, Y., Tang, W., Gao, H., Chan, E., Lan, J., and Zhou, S. (2004b). Ganoderma lucidum polysaccharide fractions accelerate healing of acetic acid-induced ulcers in rats. J. Med. Food 7, 417-421. doi: 10.1089/jmf.2004.7.417

Guo, S. A., and Dipietro, L. A. (2010). Factors affecting wound healing. J. Dental Res. 89, 219-229. doi: 10.1177/0022034509359125

Gupta, A., Kirar, V., Keshri, G. K., Gola, S., Yadav, A., Negi, P. S., et al. (2014). Wound healing activity of an aqueous extract of the Lingzhi or Reishi medicinal mushroom Ganoderma lucidum (higher Basidiomycetes). Int. J. Med. Mushrooms 16, 345-354. doi: 10.1615/IntJMedMushrooms.v16.i4.50

Hayes, W. (1976). The food value of the cultivat-ed mushroom and its importance to the mushroom industry. Mushroom J. 40, 104-110.

Huang, M.-H., and Yang, M.-C. (2008). Evaluation of glucan/poly (vinyl alcohol) blend wound dressing using rat models. Int. J. Pharmaceut. 346, 38-46. doi: 10.1016/j.ijpharm.2007.06.021

Jain, N. K., and Roy, I. (2009). Effect of trehalose on protein structure. Protein Sci. $18,24-36$

Kavishree, S., Hemavathy, J., Lokesh, B., Shashirekha, M., and Rajarathnam, S. (2008). Fat and fatty acids of Indian edible mushrooms. Food Chem. 106, 597602. doi: $10.1016 /$ j.foodchem.2007.06.018

Khamlue, R., Naksupan, N., Ounaroon, A., and Saelim, N. (2012). "Skin Wound Healing Promoting Effect of Polysaccharides Extracts from Tremella fuciformis and Auricularia auricula on the ex-vivo Porcine Skin Wound Healing Model," in 4th International Conference on Chemical, Biological and Environmental Engineering. (Singapore: IACSIT Press), 43.

Khan, M. A., Tania, M., Liu, R., and Rahman, M. M. (2013). Hericium erinaceus: an edible mushroom with medicinal values. J. Complement. Integr. Med. 10, 253-258. doi: 10.1515/jcim-2013-0001

Kim, K. H. (2017). S3-1 Discovery of new bioactive metabolites from Korean wild mushrooms. 균학회소식 29, 21-22.

Kimura, T. (2013). Natural products and biological activity of the pharmacologically active cauliflower mushroom Sparassis crispa. BioMed. Res. Int. 2013.

Kougias, P., Wei, D., Rice, P. J., Ensley, H. E., Kalbfleisch, J., Williams, D. L., et al. (2001). Normal human fibroblasts express pattern recognition receptors for fungal (1->3)-beta-D-glucans. Infection Immun. 69, 3933-3938. doi: 10.1128/ IAI.69.6.3933-3938.2001

Krupodorova, T. A., Klymenko, P. P., Barshteyn, V. Y., Leonov, Y. I., Shytikov, D. W., and Orlova, T. N. (2015). Effects of Ganoderma lucidum (Curtis) P. Karst and Crinipellis schevczenkovi Buchalo aqueous extracts on skin wound healing. J. Phytopharmacol. 4 (4), 197-201.

Kwon, A.-H., Qiu, Z., Hashimoto, M., Yamamoto, K., and Kimura, T. (2009). Effects of medicinal mushroom (Sparassis crispa) on wound healing in streptozotocin-induced diabetic rats. Am. J. Surg. 197, 503-509. doi: 10.1016/ j.amjsurg.2007.11.021

Li, C., Li, J., Li, Y., Lang, S., Yougbare, I., Zhu, G., et al. (2012). Crosstalk between platelets and the immune system: old systems with new discoveries. $A d v$. Hematol. 2012. doi: 10.1155/2012/384685

Lin, H. J., Chang, Y. S., Lin, L. H., Haung, C. F., Wu, C. Y., and Ou, K. L. (2014). An Immunomodulatory Protein (Ling Zhi-8) from a Ganoderma lucidum Induced Acceleration of Wound Healing in Rat Liver Tissues after Monopolar Electrosurgery. Evid. Based Complement. Alternat. Med. 2014, 916531. doi: $10.1155 / 2014 / 916531$

Lindequist, U., Niedermeyer, T. H., and Jülich, W.-D. (2005). The pharmacological potential of mushrooms. Evidence-Based Complement. Altern. Med. 2, 285-299.

Lowe, E. P., Wei, D., Rice, P. J., Li, C., Kalbfleisch, J., Browder, I. W., et al. (2002). Human vascular endothelial cells express pattern recognition receptors for fungal glucans which stimulates nuclear factor kappaB activation and interleukin 8 production. Winner of the Best Paper Award from the Gold Medal Forum. Am. Surg. 68, 508-518.

Malik, A. R., Wani, A. H., Bhat, M. Y., and Parveen, S. (2017). Ethnomycological knowledge of some wild mushrooms of Northern districts of Jammu and
Kashmir, India. Asian J. Pharm. Clin. Res. 10, 399-405. doi: 10.22159/ajpcr. 2017.v10i9.17641

Manjunathan, J., and Kaviyarasan, V. (2011). Nutrient composition in wild and cultivated edible mushroom, Lentinus tuberregium (Fr.) Tamil Nadu., India. Int. Food Res. J. 18, 809-811.

Manzi, P., Gambelli, L., Marconi, S., Vivanti, V., and Pizzoferrato, L. (1999). Nutrients in edible mushrooms: an inter-species comparative study. Food Chem. 65, 477-482. doi: 10.1016/S0308-8146(98)00212-X

Manzi, P., Aguzzi, A., and Pizzoferrato, L. (2001). Nutritional value of mushrooms widely consumed in Italy. Food Chem. 73, 321-325. doi: 10.1016/S0308-8146 (00)00304-6

Matuszewska, A., Stefaniuk, D., Jaszek, M., Piet, M., Zajac, A., Matuszewski, L., et al. (2019). Antitumor potential of new low molecular weight antioxidative preparations from the white rot fungus Cerrena unicolor against human colon cancer cells. Sci. Rep. 9, 1975. doi: 10.1038/s41598-018-37947-z

Minutti, C. M., Knipper, J. A., Allen, J. E., and Zaiss, D. M. W. (2017). Tissuespecific contribution of macrophages to wound healing. Semin. Cell Dev. Biol. 61, 3-11. doi: 10.1016/j.semcdb.2016.08.006

Mohamed, S. H., and Dix, N. J. (1988). Resource utilization and distribution of Coprinus comatus, C. atramentarius, Lacrimaria velutina and Melanoleuca grammopodia. Trans. Br. Mycol. Soc. 90, 255-263. doi: 10.1016/S0007-1536 (88)80097-4

Montalbano, G. (2018). Evaluation of the antimicrobial, anti-inflammatory, regenerative and wound healing properties of the bracket fungus Ganoderma lucidum. PhD. Dissertation. doi: 10.5204/thesis.eprints.116592

Mueller, A., Raptis, J., Rice, P. J., Kalbfleisch, J. H., Stout, R. D., Ensley, H. E., et al. (2000). The influence of glucan polymer structure and solution conformation on binding to (1->3)-beta-D-glucan receptors in a human monocyte-like cell line. Glycobiology 10, 339-346. doi: 10.1093/glycob/10.4.339

Müller, A., Rice, P. J., Ensley, H. E., Coogan, P. S., Kalbfleish, J. H., Kelley, J. L., et al. (1996). Receptor binding and internalization of a water-soluble (1->3)beta-D-glucan biologic response modifier in two monocyte/macrophage cell lines. J. Immunol. 156, 3418-3425.

Murugesan, S. (2017). "Sustainable Food Security: Edible and Medicinal Mushroom," in Sustainable Agriculture towards Food Security (Springer Nature Singapore Pte Ltd), 185-196.

Muszyńska, B., Grzywacz-Kisielewska, A., Kała, K., and Gdula-Argasińska, J. (2018). Anti-inflammatory properties of edible mushrooms: A review. Food Chem. 243, 373-381. doi: 10.1016/j.foodchem.2017.09.149

Nieman, D., Butterworth, D., and Nieman, C. (1992). Nutrition. Wm. C. Brown Publ. Dubugue 9, 540.

Nosenko, M. A., Ambaryan, S. G., and Drutskaya, M. S. (2019). [Proinflammatory Cytokines and Skin Wound Healing in Mice]. Mol. Biol. (Mosk) 53, 741-754. doi: $10.1134 / S 0026893319050121$

Pankavec, S., Hanc, A., Baralkiewicz, D. B., Dryzalowska, A., Zhang, J., and Falandysz, J. (2019). Mineral constituents of conserved white button mushrooms: similarities and differences. Rocz Panstw Zakl. Hig. 70, 15-25. doi: 10.32394/rpzh.2019.0051

Panneerselvam, A., Nadimuthu, N., Ambikapathy, V., Murugan, R., and Gopinathan, M. (2009). Hand book on edible mushroom cultivation. KP Print. Thanjavur 1, 71-99.

Pardeshi, B., and Pardeshi, P. (2009). "The edible medicinal mushrooms as supportive natural nutrients: Study of nonvolatile mineral contents of some edible medicinal mushrooms from India; eastern remedies for modern western maladies", in Proceedings of the 5 (th) International Medicinal Mushroom Conference.

Portera, C. A., Love, E. J., Memore, L., Zhang, L., Mueller, A., Browder, W., et al. (1997). Effect of macrophage stimulation on collagen biosynthesis in the healing wound. Am. Surgeon 63, 125-131.

Rai, M., Tidke, G., and Wasser, S. P. (2005). Therapeutic potential of mushrooms. Natural Prod. Radiance 4, 246-257.

Rajarathnam, S., Shashirekha, M. N. J., and Bano, Z. (1998). Biodegradative and biosynthetic capacities of mushrooms: present and future strategies. Crit. Rev. Biotechnol. 18, 91-236. doi: 10.1080/0738-859891224220

Rathore, H., Prasad, S., and Sharma, S. (2017). Mushroom nutraceuticals for improved nutrition and better human health: a review. PharmaNutrition 5, 3546. doi: 10.1016/j.phanu.2017.02.001 
Reis, F. S., Martins, A., Vasconcelos, M. H., Morales, P., and Ferreira, I. C. (2017). Functional foods based on extracts or compounds derived from mushrooms. Trends Food Sci. Technol. 66, 48-62. doi: 10.1016/j.tifs.2017.05.010

Ribeiro, B., Rangel, J., Valentao, P., Baptista, P., Seabra, R. M., and Andrade, P. B. (2006). Contents of carboxylic acids and two phenolics and antioxidant activity of dried portuguese wild edible mushrooms. J. Agric. Food Chem. 54, 85308537. doi: $10.1021 / \mathrm{jf061890q}$

Roncero-Ramos, I., and Delgado-Andrade, C. (2017). The beneficial role of edible mushrooms in human health. Curr. Opin. Food Sci. 14, 122-128. doi: 10.1016/ j.cofs.2017.04.002

Rony, K. A., Mathew, J., Neenu, P. P., and Janardhan, K. K. (2011). Ganoderma lucidium (Fr.) P. Karst. Occurring in South India attenuates gastric ulcerations in rats. Indian J. Nat. Prod. Res. 2, 19-27.

Roupas, P., Keogh, J., Noakes, M., Margetts, C., and Taylor, P. (2012). The role of edible mushrooms in health: Evaluation of the evidence. J. Funct. Foods 4, 687709. doi: $10.1016 / j . j f f .2012 .05 .003$

Rózsa, S., Măniuțiu, D.-N., Poșta, G., Gocan, T.-M., Andreica, I., Bogdan, I., et al. (2019). Influence of the Culture Substrate on the Agaricus blazei Murrill Mushrooms Vitamins Content. Plants (Basel Switzerland) 8, 316.

Ruthes, A. C., Smiderle, F. R., and Iacomini, M. (2016). Mushroom heteropolysaccharides: A review on their sources, structure and biological effects. Carbohydr. Polym. 136, 358-375. doi: 10.1016/j.carbpol.2015.08.061

Sánchez, C. (2010). Cultivation of Pleurotus ostreatus and other edible mushrooms. Appl. Microbiol. Biotechnol. 85, 1321-1337. doi: 10.1007/s00253-009-2343-7

Sánchez, C. (2017). Reactive oxygen species and antioxidant properties from mushrooms. Synthetic Syst. Biotechnol. 2, 13-22. doi: 10.1016/j.synbio. 2016.12.001

Schepetkin, I. A., and Quinn, M. T. (2006). Botanical polysaccharides: macrophage immunomodulation and therapeutic potential. Int. Immunopharmacol. 6, 317333. doi: 10.1016/j.intimp.2005.10.005

Seo, G., Hyun, C., Choi, S., Kim, Y. M., and Cho, M. (2019). The wound healing effect of four types of beta-glucan. Appl. Biol. Chem. 62, 20. doi: 10.1186/ s13765-019-0428-2

Sokół, S., Golak-Siwulska, I., Sobieralski, K., Siwulski, M., and Górka, K. (2016). Biology, cultivation, and medicinal functions of the mushroom Hericium erinaceum. Acta Mycol. 50, 1069.

Sui, Z., Yang, R., Liu, B., Gu, T., Zhao, Z., Shi, D., et al. (2010). Chemical analysis of Agaricus blazei polysaccharides and effect of the polysaccharides on IL-1beta mRNA expression in skin of burn wound-treated rats. Int. J. Biol. Macromol. 47, 155-157. doi: 10.1016/j.ijbiomac.2010.05.006

Sureda, A., Batle, J. M., Martorell, M., Capó, X., Tejada, S., Tur, J. A., et al. (2016). Antioxidant Response of Chronic Wounds to Hyperbaric Oxygen Therapy. PloS One 11, e0163371-e0163371. doi: 10.1371/journal.pone.0163371

Taofiq, O., González-Paramás, A. M., Martins, A., Barreiro, M. F., and Ferreira, I. C. (2016). Mushrooms extracts and compounds in cosmetics, cosmeceuticals and nutricosmetics-A review. Ind. Crops Prod. 90, 38-48. doi: 10.1016/ j.indcrop.2016.06.012

Thangaraj, R., Raj, S., and Renganathan, K. (2017). Wound healing effect of king alferd's mushroom (Daldinia concentrica) used by tribes of sirumalai hills, Tamilnadu, India. Int. J. Pharm. Pharm. Sci. 9, 161-164. doi: 10.22159/ ijpps.2017v9i7.20628

Thimal, R., and Kluthe, R. (1998). The nutritional database for edible mushrooms. Ernahrung 22, 63-65.
Trovato, A., Pennisi, M., Crupi, R., Di Paola, R., Alario, A., Modafferi, S., et al. (2017). Neuroinflammation and Mitochondrial Dysfunction in the Pathogenesis of Alzheimer's Disease: Modulation by Coriolus Versicolor (Yun-Zhi) Nutritional Mushroom. J. Neurol. Neuromed. 2, 19-28. doi: 10.29245/2572.942X/2017/2.942X/2017/1.1088

Turkoglu, A., Duru, M. E., Mercan, N., Kivrak, I., and Gezer, K. (2007). Antioxidant and antimicrobial activities of Laetiporus sulphureus (Bull.) Murrill. Food Chem. 101, 267-273. doi: 10.1016/j.foodchem.2006.01.025

Verma, R. K., Pandro, V., Mishra, S. N., Raj, D., and Asaiya, A. J. K. (2019). Sal Forest: A Source of Wild Edible Mushrooms for Livelihood Support to Tribal People of Dindori District, Madhya Pradesh, India. Int. J. Curr. Microbiol. Appl. Sci. 8, 563-575. doi: 10.20546/ijcmas.2019.801.063

Wakefield, E. M. (1964). The Observer"s Book of Common Fungi, 2nd Edn. (Frederick Warne \& Co. Ltd.).

Wang, X.-M., Zhang, J., Wu, L.-H., Zhao, Y.-L., Li, T., Li, J.-Q., et al. (2014). A mini-review of chemical composition and nutritional value of edible wildgrown mushroom from China. Food Chem. 151, 279-285. doi: 10.1016/ j.foodchem.2013.11.062

Yamamoto, K., and Kimura, T. (2013). Orally and topically administered Sparassis crispa (Hanabiratake) improved healing of skin wounds in mice with streptozotocin-induced diabetes. Biosci. Biotechnol. Biochem. 77, 1303-1305. doi: $10.1271 /$ bbb.121016

Yang, Z., Xu, J., Fu, Q., Fu, X., Shu, T., Bi, Y., et al. (2013). Antitumor activity of a polysaccharide from Pleurotus eryngii on mice bearing renal cancer. Carbohydr. Polym. 95, 615-620. doi: 10.1016/j.carbpol.2013.03.024

Yoon, S. J., Yu, M. A., Pyun, Y. R., Hwang, J. K., Chu, D. C., Juneja, L. R., et al. (2003). The nontoxic mushroom Auricularia auricula contains a polysaccharide with anticoagulant activity mediated by antithrombin. Thromb. Res. 112, 151-158. doi: 10.1016/j.thromres.2003.10.022

Yu, Z., Lihua, Y., Qian, Y., and Yan, L. (2009). Effect of Lentinus edodes polysaccharide on oxidative stress, immunity activity and oral ulceration of rats stimulated by phenol. Carbohydr. Polym. 75, 115-118. doi: 10.1016/ j.carbpol.2008.07.002

Zengin, G., Uren, M. C., Kocak, M. S., Gungor, H., Locatelli, M., Aktumsek, A., et al. (2017). Antioxidant and Enzyme Inhibitory Activities of Extracts from Wild Mushroom Species from Turkey. Int. J. Med. Mushrooms 19, 327-336. doi: 10.1615/IntJMedMushrooms.v19.i4.30

Zhao, X. K., Cheng, Y., Liang Cheng, M., Yu, L., Mu, M., Li, H., et al. (2016). Focal Adhesion Kinase Regulates Fibroblast Migration via Integrin beta-1 and Plays a Central Role in Fibrosis. Sci. Rep. 6, 19276. doi: 10.1038/srep19276

Conflict of Interest: The authors declare that the research was conducted in the absence of any commercial or financial relationships that could be construed as a potential conflict of interest.

Copyright $\odot 2020$ Sharifi-Rad, Butnariu, Ezzat, Adetunji, Imran, Sobhani, Tufail, Hosseinabadi, Ramirez-Alarcón, Martorell, Maroyi and Martins. This is an openaccess article distributed under the terms of the Creative Commons Attribution License (CC BY). The use, distribution or reproduction in other forums is permitted, provided the original author(s) and the copyright owner(s) are credited and that the original publication in this journal is cited, in accordance with accepted academic practice. No use, distribution or reproduction is permitted which does not comply with these terms. 